\title{
REPRESENTASI PEREMPUAN BERDAYA PADA AKUN INSTAGRAM @RACHELVENNYA
}

\section{REPRESENTATION OF EMPOWERED WOMEN ON INSTAGRAM ACCOUNT @RACHELVENNYA}

\author{
Asmaul Husna ${ }^{1}$, Yuhdi Fahrimal ${ }^{2}$ \\ ${ }^{12}$ Program Studi Ilmu Komunikasi, Universitas Teuku Umar \\ J1. Alue Peuyareng, Kampus UTU, Aceh Barat, Indonesia \\ 1'asmaulhusna@utu.ac.id; ${ }^{2}$ yuhdifahrimal@utu.ac.id \\ Diterima tgl. 27/02/2021; Direvisi tgl. 17/08/2021; Disetujui tgl. 22/11/2021
}

\begin{abstract}
The digital era opens up opportunities for women not only to represent their existence but to take advantage of increasing their capacity to be more empowered in education and the economy without having to leave their role in the family. The purpose of this study is to analyze and explain the self-representation of women who are empowered in the digital era, especially on social media. The research method used was qualitative content analysis with the object of the study on the Instagram account@Rachelvennya's. Based on the results of tracking, coding, and data analysis, it was found that Rachel Vennya represented herself as an instafamous and a womanpreneur who still prioritized her family. The forms of self-representation are economic independence, the importance of education for women, prioritizing family, women must be able to lead, and women can express themselves. This study concludes that Rachel Vennya is proof that women who can represent themselves as unskilled figures in the domestic area but also have the opportunity to become inspirations and leaders in the digital era.
\end{abstract}

Keywords: Empowered Women, Social Media, Self-Representation.

\begin{abstract}
ABSTRAK
Era digital membuka peluang bagi perempuan bukan hanya untuk merepresentasikan eksistensi diri, tetapi dapat dimanfaatkan bagi peningkatan kapasitas diri untuk lebih berdaya secara pendidikan dan ekonomi tanpa harus meninggalkan peran mereka dalam keluarga. Tujuan penelitian ini adalah untuk menganalisis dan menjelaskan representasi diri perempuan berdaya di era digital khususnya di media sosial. Metode penelitian yang digunakan adalah analisis konten kualitatif dengan objek kajian akun Instagram @ RachelVennya. Berdasarkan hasil penelurusan, koding, dan analisis data ditemukan bahwa Rachel Vennya merepresentasikan diri sebagai pesohor Instagram dan pengusaha perempuan yang tetap memprioritaskan kehidupan domestiknya di keluarga. Bentuk-bentuk representasi dirinya adalah berdikari secara ekonomi, pentingnya pendidikan bagi perempuan, mengutamakan keluarga, perempuan harus mampu memimpin, dan perempuan dapat berekspresi. Penelitian ini menyimpulkan bahwa Rachel Vennya adalah sebuah bukti bahwa perempuan mampu merepresentasikan diri mereka sebagai sosok yang tidak hanya terampil di area domestik, tetapi juga berpeluang menjadi inspirator dan pemimpin di era digital.
\end{abstract}

Kata Kunci: Perempuan Berdaya, Media Sosial, Representasi Diri

\section{PENDAHULUAN}

Sejak media sosial berkembang seiring dengan meningkatnya kebutuhan, kreativitas, dan laju teknologi maka kajian terkait perilaku pengguna, intensitas penggunaan, akses, dan dampak media sosial dalam kehidupan individu dan masyarakat mulai menjadi fokus para peneliti (Sloan \& QuanHaase, 2017). Berbagai perspektif dan pendekatan interdisiplin digunakan untuk membedah praktik perilaku pengguna internet dan media sosial dalam keseharian (Hunsinger et al., 2020). Ngai et al. (2015) mencatat berbagai teori dan metodologi juga dipakai oleh peneliti untuk mengungkap realita perilaku individu dan praktik interaksi di dalam media sosial. Fokus kajian media sosial pun beragam, seperti identitas diri (Pan et al., 2017; O'Donnell, 2018), pemenuhan atas kebutuhan informasi (Karapanos et al., 2016), presentasi diri (Bouvier, 2012; Smith \& Sanderson, 2015), 
aktualisasi dan harga diri (Mehdizadeh, 2010; Best, 2016; Jan et al., 2017), konsep diri (Sponcil \& Gitimu, 2013), dan citra diri (Purwaningtyas \& Alicya, 2020).

Media sosial berkembang sebagai saluran komunikasi termediasi komputer dan teknologi jaringan yang menghubungkan antar-peserta komunikasi dalam dialog yang lebih inetraktif tanpa harus memikirkan kendala ruang dan waktu (Masse, 2017; Rachmansyah \& Supratman, 2020). Salah satu aplikasi media sosial yang digandrungi oleh khalayak adalah Instagram. Hingga tahun 2020, pengguna Instagram tercatat mencapai 1 milyar pengguna meningkat miliaran-juta users sejak awal diluncurkan ke publik pada 6 Oktober 2010 dengan hanya 40.000 pengguna awal (Caldeira, 2016; Enberg, 2020). Indonesia menempati negara ke-empat users Instagram terbanyak di dunia dengan jumlah akun aktif 85 juta pengguna (Handayani \& Adelvia, 2020; Statista.com, 2021).

Instagram menyediakan beragam fitur editing foto yang estetik, memudahkan orang-orang awam untuk memperbaiki kualitas foto yang mirip fotografer profesional, dan memungkinkan users untuk saling berbagi momen dalam bentuk foto dan video mereka kepada jejaring pertemanan (Caldeira, 2016; O’Donnell, 2018; Smith \& Sanderson, 2015). Pola algoritma Instagram juga memungkin orang-orang untuk menjangkau lebih banyak pengguna melalui \#hastag sehingga tidak jarang menjadi viral dan penggunanya berubah menjadi social media influencer atau "selebgram" istilah untuk merujuk pengguna dengan jumlah pengikut yang banyak dan menjadi idola baru khalayak (Djafarova \& Trofimenko, 2019; Ruiz-Gomez, 2019).

Permasalahan utama yang mendasari penelitian ini dilakukan, yakni, bagaimana representasi diri perempuan berdaya di era digital? Riset ini didasarkan pada asumsi bahwa era digital telah membuka jalan baru bagi perempuan untuk berdayaguna dengan menyeimbangkan kehidupan domestiknya (Lestari et al., 2020). Keberadaan media sosial seperti Instagram menjadi jembatan bagi aktualisasi diri perempuan sehingga mereka dapat melakukan hal yang mereka sukai dengan tetap mempedulikan kehidupan keluarganya.

Representasi diri perempuan berdaya yang mampu menyeimbangkan kehidupan personal dan posisinya di ruang publik pada era digital menjadi topik yang menarik untuk dikaji. Media sosial sebagai saluran komunikasi digital menyediakan ruang bagi perempuan untuk (1) terhubung dengan jejaring yang lebih luas dan dengan beragam latar belakang sosio-ekonomi (networking space); (2) mengembangkan diri dengan belajar banyak hal dan berbagi informasi (information space); dan (3) membantu perekonomian keluarga melalui promosi dan penjualan (economic space).

Menurut Rettberg (2018) representasi diri merupakan konstruksi objek, tanda, dan citra yang sengaja dibangun baik sesuai dengan realita maupun di luar realita itu sendiri. Sederhananya, representasi didasarkan pada tujuan yang ingin dicapai oleh seseorang. Dodson (2015) menyatakan bahwa di era digital, representasi diri merupakan bentuk kecil dari identitas digital yang digunakan orang-orang untuk berinteraksi dalam ruang yang lebih besar. Mengikuti pendapat Rettberg (2018) bahwa mengkaji representasi diri di era digital membuka kemungkinan kita untuk melihat presentasi diri melalui foto, video, selfie, tweet, dan tampilan grafis lainnya.

Riset-riset terkait perempuan dan media sosial telah banyak dilakukan, tetapi berfokus pada pembentukan citra diri, perilaku bermedia sosial, personal branding, dan meningkatkan eksistensi diri dalam jaringan pertemanan yang luas (Islami, 2018; Mahendra, 2017; Permatasari \& Trijayanto, 2017). Padahal media sosial dapat dimanfaatkan sebagai alternatif pekerjaan bagi perempuan yang ingin membantu perkenomian keluarga, tetapi tetap ingin berada di ranah domestiknya. Riset An Nur \& Hariyanti (2019) menunjukkan bahwa kehadiran media sosial dapat dimanfaatkan bagi perempuan untuk menjadi beauty vlogger yang memungkinkan mereka melakukan aktivitas yang mereka suakai, berbagi informasi produk dan trik merias diri, dan 
menghasilkan uang dari aktivitas mereka tersebut. Demikian pula dengan riset Silva et al. (2020) yang menunjukkan bahwa menjadi digital influencer memungkinkan akun dengan pengikut yang banyak menghasilkan uang dari endorsement produk. Dengan kemajuan teknologi komunikasi saat ini, perempuan bisa melakukan berbagai aktivitas, mulai dari mengerjakan tugas kantor, berjualan secara daring, menggerakkan masyarakat maupun komunitas melalui media sosial.

\subsection{Instagram: Media Representasi Diri}

Representasi atau dalam Bahasa inggris disebut dengan represent yang berarti perwakilan ataupun penggambaran (Krebs, 2001). Dalam makna yang sederhana, representasi dapat diartikan sebagai gambaran mengenai suatu hal yang terdapat dalam kehidupan yang digambarkan melalui media (Milrod, 2002; Caldeira, 2016; Rettberg, 2018). Terminologi representasi diri secara konvensional digagas oleh Erving Goffman (dalam Dodson, 2015) yang melihat representasi diri sebagai pembentukan citra diri agar sesuai dengan konteks sosial dalam interaksi tatap muka. Pada fase berikutnya, terminologi dari Goffman tersebut dikritik dan dikembangkan oleh para ilmuan sosial, psikologi, dan komunikasi dengan melihat bahwa representasi diri sebagai sebuah konstruksi sosial yang mengharuskan kita mengeksplorasi pembentukan makna tekstual dan menghendaki penyelidikan tentang cara dihasilkannya makna pada beragam konteks. Mereka diproduksi, ditampilkan, digunakan, dan dipahami dalam konteks sosial tertentu (Dodson, 2015).

Representasi cenderung merujuk pada bagaimana seseorang, kelompok ataupun gagasan tertentu ditampilkan dalam sebuah wacana (Rettberg, 2018). Representasi memungkinkan untuk memaknai dunia dengan mengkonstruksi seperangkat rantai korespondensi antar sesuatu dengan peta konseptual dengan mengunakan bahasa atau simbol yang berfungsi mempresentasikan konsepkonsep yang dalam pikiran kita tentang sesuatu (Kosakoy, 2016). Stuart Hall membagi tiga pendekatan representasi, yaitu (1) reflective approach yang merujuk bahwa representasi mencerminkan realitas yang sebenarnya; (2) intentional approach yang mengajukan asumsi bahwa makna representasi objek dan tanda hanya ada pada pembuatnya; dan (3) constructive approach yang menyatakan bahwa representasi merupakan sebuah kesengajaan yang dikonstruksi dan mengalami dialektika makna antara pencipta dan penerima tanda (Rettberg, 2018; Sender \& Decherney, 2016).

Menurut Fahrimal (2018) media digital membawa pengaruh besar bagi individu untuk mengaktualisasikan dan merepresentasikan dirinya. Bentuk-bentuk representasi diri di era digital dikonstruksi sedemikian rupa sehingga terkadang jauh dari realitas sebenarnya. Beragam aplikasi sosial media menyediakan fasilitas untuk memperindah foto agar lebih estetis, alih-alih hanya berfungsi sebagai jejaring media sosial saja (Fahrimal, 2018). Menurut Rettberg (2018) representasi diri dan interpretasi di media sosial dipengaruhi oleh dua faktor, yaitu (1) faktor internal berhubungan dengan pengalaman dan interpretasi yang berbeda terhadap realitas dan (2) faktor sosio-kultural berkaitan dengan perbedaan latar belakang budaya berimplikasi pada perbedaan interpretasi terhadap representasi. Dengan kata lain representasi bersifat subjektif, sebab penggambaran yang ditampilkan bisa baik atau justru sebaliknya. Sejatinya representasi bukan penjiplakan atas kenyataan yang sesungguhnya, melainkan ekspresi estetis, rekonstruksi dari situasi sesungguhnya. Sehingga dalam konteks kajian ini, representasi merujuk pada salah satu cara untuk memproduksi makna yang diwujudkan melalui kata, teks, gambar, maupun gambar bergerak.

Dewasa ini, swafoto tengah menjadi tren di tengah masyarakat seiring menjamurnya jejaring sosial berbasis visual. Mengabadikan foto dengan berbagai pose dan ekspresi untuk kemudian di unggah pada album virtual layaknya Instagram seolah menjadi sebuah keharusan bagi beberapa individu (Atmoko, 2012). Tidak mengherankan jika hingga saat ini pengguna aktif Instagram per bulannya mencapai angka 1 miliar lebih. 
Instagram menjadi media ter up to date. Segala kejadian di dunia yang terekam dapat terpublikasi di Instagram. Mulai dari fashion, kecantikan, makanan, hingga destinasi wisata malang melintang di dalamnya. Bahkan bagi penggunanya, angka likes dan followers menjadi sebuah tolak ukur dan pembuktian tersendiri apakah akun mereka diminati atau tidak oleh pengguna lain. Maka tidak jarang untuk memposting sebuah foto atau video, para pengguna Instagram akan bersusah payah untuk memoles gambar dirinya dengan filter maupun software editing hanya sekedar untuk pembuktian kepada dunia luar atas keberadaan dirinya. Praktis, instagram menjelma ibarat sebuah panggung dimana seseorang berlomba-lomba untuk memenuhi keinginan mereka demi menampilkan diri sehubungan dengan keinginannya untuk dilihat dan diakui oleh orang lain (Belinska, 2018). Instagram kini telah menjelma layaknya sebuah panggung aktualisasi diri sekaligus private diary seseorang. Dalam konteks kajian ini, kita akan melihat bagaimana kontenkonten yang diunggah pada laman jejaring sosial instagram menjadi sebuah cara bagi perempuan untuk menunjukkan potensi serta eksistensinya di hadapan publik.

\subsection{Representasi Perempuan Berdaya di Era Digital}

Perempuan berdaya merupakan sebuah konsepsi kritis untuk mendobrak dominasi patriarki. Selama ini posisi subordinat perempuan yang dikonstruksi masyarakat menjadikan perempuan dipandang lebih rendah dibandingkan laki-laki. Setiap langkah dan keinginan perempuan harus didasarkan pada "restu" laki-laki yang menjadi keluarganya baik itu ayah, suami, paman, atau saudara laki-laki. Menurut Supratman (2012) kondisi tersebut telah memicu lahirnya gerakan feminisme yang berkembang sejak abad ke-19 bahwa perlu perjuangan perempuan untuk keluar dari posisi subordinasinya.

Sebagai sebuah gerakan dan ideologi, feminisme sendiri mengalami pertentangan dan kritik bahkan oleh sesama pembela feminisme sendiri. Misalnya ide feminisme gelombang kedua yang ingin kesetaraan bidang politik dan budaya bagi perempuan ditentang oleh aktivis feminisme gelombang ketiga (dimulai awal 1990an) karena dianggap terlalu berfokus pada citra diri perempuan barat (Rampton, 2008). Di sisi lain feminisme gelombang ketiga juga mendapat kritik karena ketidakstabilan konstruksi atas gagasan "kewanitaan universal" (universal womenhood), tubuh, gender, seksualitas, dan heteronormativitas (Rampton, 2008).

Meskipun konseptualisasi feminisme masih mendapat pertentangan, feminisme cukup konsisten dalam upaya mengubah konstruksi sosial terhadap perempuan. Gerakan feminisme mendobrak sekat-sekat sosio-kultural yang menghalangi perempuan untuk berkembang. Menurut Peterson et al. (2008) feminisme telah terbukti mampu untuk menumbuhkan kesadaran perempuan untuk mengganti posisi mereka dari objek konstruksi sosial dan media menjadi subjek yang menentukan keinginan dan nasib mereka sendiri. Perjuangan feminisme terus berlanjut dengan mengembangkan berbagai isu dan tujuannya serta penggunaan berbagai saluran komunikasi untuk mengadvokasi isu-isu perempuan.

Kemajuan teknologi digital membuka ruang bagi setiap orang untuk terlibat dalam aktifitas digital. Internet menjadi ruang publik baru bagi warga negara untuk bertukar informasi, mengungkapkan pendapat dan gagasan, membangun lingkungan pertemanan baru, hingga transaksi ekonomi (Dodson, 2015; Isyfi'afiani, 2018; Lestari et al., 2020). Dalam kaitannya dengan feminisme, keberadaan teknologi digital telah membuka ruang baru bagi gerakan feminisme, yakni feminisme siber (cyber feminisme) (McAdam et al., 2020). Gagasan feminisme siber yang dicetuskan oleh Plant (1997) yang memandang bahwa teknologi informasi dan komunikasi berguna sebagai wadah dimana perempuan dapat merasa cukup nyaman untuk sejahtera. Digitalisasi menawarkan berbagai peluang untuk pemberdayaan perempuan dan partisipasi perempuan yang lebih setara di pasar tenaga kerja, pasar keuangan, dan kewirausahaan. 
Dalam perkembangannya feminisme siber memiliki dua arah penyelidikan, yaitu pertama kelompok periset yang berargumentasi bahwa kehidupan online yang dijalani perempuan merupakan replikasi dari kehidupan nyata mereka di lingkungan sosial (McAdam et al., 2020). Dasar dari argumentasi ini adalah bahwa di internet, perempuan masih mengalami pembatasan dalam hal akses, penggunaan, keterampilan, dan persepsi atas diri mereka (Dy et al., 2017; McAdam et al., 2020). Riset Duffy \& Pruchniewska (2017) menemukan bahwa tidak jarang perempuan pekerja harus merepresentasikan diri dalam feminitas tradisional saat mereka berada di ruang digital. Tuntutan besar lembaga sosial dimana perempuan berada membuat perempuan hanya mereplikasi peran mereka di kehidupan nyata ke dalam dunia maya. Padahal menurut Daniels (2013) ruang virtual sama sekali berbeda dengan ruang nyata dimana faktor-faktor gender harusnya ditinggalkan dan penggunanya dapat melakukan hal apa pun dengan tetap mempertimbangkan tanggung jawab personal.

Kedua, argumentasi bahwa dunia maya berpotensi untuk menjadi ruang egaliter dan memberikan peluang baru bagi representasi perempuan (McAdam et al., 2020). Dalam pandangan ini ruang maya diposisikan sebagai ruang yang bebas khususnya bagi perempuan untuk meninggalkan tubuh dan gender mereka sehingga mereka dapat bebas dari pengekangan fisik dan sosial sebagaimana yang mereka dapatkan di lingkungan sosial. Brophy (2010) menyatakan sesungguhnya paradigma yang mendorong kebebasan mutlak di internet terhadap perempuan ini sebagai sebuah cyberutopia, yaitu kondisi dimana kebebasan mutlak bagi perempuan dengan meninggalkan tubuh dan gendernya hanya sebatas idealita. Oleh karena itu, menurut Brophy (2010) feminis siber seharusnya tidak memandang ruang maya sebagai wadah untuk menggantikan pengalaman hidup, tetapi hanya sebagai augmentasi saat perempuan membutuhkan saluran untuk "membuang" kepenatan dunia nyata.

Riset ini bergerak dari pendapat McAdam et al. (2020) bahwa internet menjadi ruang baru bagi perempuan untuk berdaya. Konsepsi perempuan berdaya di era digital adalah perempuan yang memiliki daya saing, daya sanding, dan daya saring dalam menjalani kehidupan di era digital. Meski tidak dapat dipungkiri, perjuangan kaum perempuan untuk bersaing di era digital mungkin sedikit agak sulit mengingat posisi perempuan yang memiliki peran ganda atau double burden, yaitu keadaan yang menempatkan seorang perempuan harus menanggung pekerjaan pada ranah domestik dan juga publik khususnya bagi perempuan di negara dunia ketiga. Akan tetapi, kemajuan teknologi digital memberikan kesempatan yang sama kepada peremuan untuk berpartisipasi dalam berbagai sektor baik ekonomi (Dewi, 2020; McAdam et al., 2020; Ughetto et al., 2020), sosial budaya (Bt Mahmud et al., 2019; Gajjala \& Wauthier, 2020); hingga politik (Caldeira et al., 2020a).

Perempuan yang berdaya adalah perempuan yang memiliki kekuatan untuk melakukan hal-hal positif dalam hidupnya sekaligus membuat pilihan dalam hidupnya. Tidak ada indikator yang cukup memadai untuk menilai keberdayaan perempuan. Kurniawati et al. (2019); Purnamawati (2012); dan Saputri \& Himam (2015) menyatakan bahwa perempuan berdaya adalah perempuan yang mandiri, mampu mengembangkan diri, mampu membagi waktu antara pekerjaan dan keluarga, memiliki passion dalam melakukan sesuatu, peka terhadap lingkungan, serta memiliki wawasan yang luas. Sedangkan Peterson et al. (2008) dengan mengutip konsep Rogers et al. (1997) menyatakan bahwa perempuan berdaya adalah perempuan yang memiliki (1) self-esteem dan selfefficacy yang berkaitan dengan dorongan perempuan untuk mencapai apa yang ingin ia lakukan; (2) kekuatan atau ketidakbedayaan untuk mengontrol keputusan pribadi dan sosial; (3) aktivisme dan otonomi individu/komunitas berkaitan individu/kelompok mampu mempengaruhi perubahan diri dan sosial; (4) optimisme dan kontrol atau masa depan berkaitan dengan pandangan positif untuk 
masa depan; dan (5) righteous anger yakni berkaitan dengan keyakinan bahwa seseorang dapat memanfaatkan kemarahan dengan cara positif untuk mencapai tujuan.

Representasi perempuan berdaya di era digital menjadi sebuah topik menarik untuk diteliti, mengingat selama ini riset-riset yang ada memperlihat adanya ketidakadilan gender bagi perempuan dalam hal akses mereka terhadap media sosial. Penelitian Rosyidah \& Nurdin (2018) menemukan bahwa media sosial menjadi ruang baru bagi terjadinya kekerasan seksual pada perempuan khususnya yang berusia remaja. Riset Tortajada et al. (2013) menemukan bahwa potensi pelecehan seksual terhadap remaja perempuan dapat terjadi karena adanya trigger dari postingan di media sosial mereka. Ekspresi diri dengan menampilkan citra diri yang seksi dan cantik mendorong terjadinya stereotipe gender. Terlebih dalam media sosial anonimitas mungkin saja terjadi. Di sisi lain (Dewi, 2019) melihat bahwa masyarakat masih sulit membedakan antara candaan dan pujian yang sebenarnya merupakan pelecehan seksual khususnya secara verbal (catcalling).

Terkait perilaku menggunakan media sosial, kajian Kurniawati (2020) menemukan bahwa terjadi perubahan mendasar terhadap cara perempuan menunjukkan citra dirinya, sehingga selfie menjadi perilaku lazim untuk memediatisasi tubuh perempuan. Dalam hal eksistensi diri, riset Putri (2018) yang menemukan bahwa kebanyakan para influencer justru lebih banyak menampilkan gaya hidup hedonism yang terkadang berbeda jauh dengan kelas ekonomi para pengikut mereka di media sosial. Sedangkan Rahayu (2015) menyatakan bahwa perempuan dapat menjadi aktor utama dalam kontestasi di era digital. Dalam hal kesiapan terhadap perubahan, perempuan dikenal paling siap dan adaptif. Akan tetapi, kehalusan rasa yang dimiliki perempuan yang kadang menjebaknya untuk memilih kompromi ketimbang kompetisi. Hanya saja, belum semua perempuan menyadari potensi yang mereka miliki dan memanfaatkannya dengan maksimal.

Tujuan utama penelitian adalah untuk mengungkap, menganalisis, dan menjelaskan representasi perempuan berdaya di era digital. Kajian ini mengambil fokus pada akun Instagram Rachel Vennya (@Rachelvennya) melalui penelisikan postingan-postingan yang menggambarkan dirinya sebagai perempuan berdaya. Riset ini diharapkan dapat menambah khazanah kajian dan konseptualisasi representasi diri perempuan berdaya di era digital. Penelitian yang ada terbatas pada representasi tubuh perempuan dalam media sosial. Menurut pandangan peneliti representasi tubuh berbeda dengan representasi diri. Representasi tubuh terbatas pada perilaku eksploitasi tubuh untuk mengikuti logika media. Oleh karenanya dalam kerangka representasi tubuh, para users cenderung akan menampilkan bentuk-bentuk tubuh yang dianggap ideal (Kertamukti et al., 2018), seksi (Van Ouytsel et al., 2020), atau pun sehat (Vandenbosch, 2017). Dalam makna yang lebih luas, representasi diri merupakan bentuk-bentuk simbolik yang melebihi presentasi tubuh untuk menunjukkan identitas, aktualisasi diri, citra diri, dan harga diri (Djafarova \& Trofimenko, 2019; Dodson, 2015; Rettberg, 2018; Thumim, 2012).

\section{METODE PENELITIAN}

Rachel Vennya dapat dikategorikan sebagai sosok yang fenomenal di era digital. Bukan hanya karena usianya yang terbilang muda dan bayaknya pengikut di Instagramnya, citra diri sebagai ibu, istri, influencer, dan womenpreneur. Semua label tersebut merupakan citra diri yang dikonstruksi oleh Rachel Vennya di jagat digital. Oleh karenanya mengkaji representasi diri Rachel Vennya dalam kerangka perempuan yang berdaya di era digital mendapatkan relevansi dan signifikansinya. Pengambilan objek kajian akun Instagram @ Rachelvennya dilakukan dengan pertimbangan seperti (1) Rachel Vennya sebagai seorang istri dan ibu muda yang mecitrakan wanita masa kini yang aktif di media sosial khususnya Instagram dengan rutin membagikan momen; (2) Rachel Vennya 
sebagai influencer yang memiliki 5,3 juta followers di akun Instagramnya; (3) Rachel Vennya juga sebagai pengusaha bidang fashion dan kuliner dengan beberapa merek dagang.

Objek penelitian ini adalah akun Instagram @ Rachelvennya yang sudah verified (centang

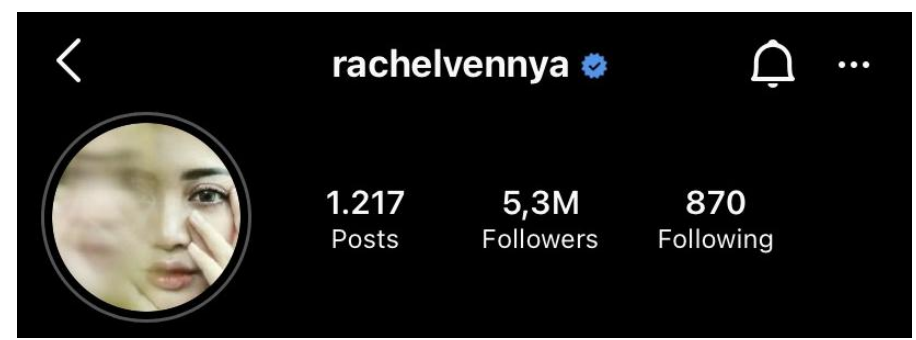

biru). Pemilihan objek penelitian ini didasarkan pada latar belakang Rachel Vennya sebagai ibu, istri, influencer, dan pengusaha yang membangun semuanya dari bawah. Penelitian ini menggunakan pendekatan kualitatif dengan metode content analysis. Metode ini peneliti gunakan karena batasan penelitian hanya mengkaji, menginterpretasi, dan mendeskripsikan bentuk representasi diri Rachel Vennya sebagai perempuan berdaya di era digital (Caldeira et al., 2020b; Enli \& Thumim, 2012; Graneheim et al., 2017).

Sumber: Instagram @ Rachelvennya

Gambar 1. Identitas Akun Instagram Rachel Vennya

Penelitian ini melalui beberapa tahapan, yaitu pertama peneliti mengumpulkan data foto dan video dari feed Instagram @Rachelvennya dengan jumlah followers sebanyak 5,3 juta. Hasil penelusuran dan pengumpulan awal foto dan video dari akun Rachel Vennya didapatkan sebanyak 1217 postingan. Proses ini melibatkan tiga orang coder, yaitu satu peneliti utama, satu asisten peneliti, dan satu orang dosen Prodi Ilmu Komunikasi, FISIP, Universitas Teuku Umar. Hal ini dikukan untuk memvalidasi temuan foto dan menghindari bias dalam pemilihan foto dan analisis data.

Kedua, peneliti mereduksi data sesuai dengan tujuan penelitian. Proses reduksi data ini dilakukan untuk memisahkan postingan-postingan yang berulang termasuk memisahkan momen yang sama meskipun berbeda angle foto dan video. Ketiga, postingan yang sudah direduksi selanjutnya dilakukan koding untuk mengelompokkan postingan sesuai dengan tema-tema yang ditetapkan untuk merujuk representasi diri di era digital (Caldeira et al., 2020b; Rettberg, 2018). Tema-tema tersebut, yaitu (1) keluarga; (2) pendidikan; (3) jiwa sosial; (4) kemandirian; (5) kepemimpinan; dan (6) entrepreneurship. Ke-empat, foto dan video yang telah dikelompokkan dalam tema-tema tersebut selanjutnya dianalisis menggunakan kerangka representasi diri.

Dalam proses analisis data, caption atau keterangan pada setiap postingan foto dan video juga dianalisis untuk mengetahui makna dan tujuan foto atau video tertentu di posting oleh pengguna. Dokumen dan artikel terkait tujuan penelitian juga digunakan dalam tahap analisis data. Hal ini dilakukan untuk mempertajam analisis, membandingkan hasil penelitian dengan riset terdahulu, mencari argumentasi ilmiah untuk temuan penelitian yang didapatkan, serta mencapai validitas data hasil penelitian dan untuk menghidari bias.

\section{HASIL DAN PEMBAHASAN}

Berdasarkan pantauan postingan dari akun Instagram @Rachelvennya, terlihat bahwa unggahan foto dan video Rachel Vennya berfokus pada daily activity baik sebagai istri, ibu, influencer, dan womenpreneur. Aktivitas sosialita yang biasanya ditunjukkan oleh kebanyakan influencer tidak terlalu banyak didapatkan dari postingan Rachel Vennya. Ia lebih banyak 
mengunggah foto-foto keluarganya khususnya anak-anaknya yang masih kecil, yaitu Xabiru Oshe Al Hakim dan Aurorae Chava Al Hakim.

Terkait dengan representasi diri Rachel Vennya, secara garis besar gagasan mengenai representasi perempuan berdaya di era digital dapat diklasifikasikan ke dalam lima tema utama. Deskripsi terhadap lima tema tersebut:

\subsection{Perempuan Harus Mampu Berdikari}

Sejatinya perempuan berdikari adalah perempuan yang mampu mengaktualisasikan potensi dirinya lebih dari sekedar aktivitas di ranah domestik. Perempuan berdikari tidak dimaksudkan untuk melawan kodrat yang mereka miliki baik secara nature, nurture, maupun culture (Kuncoro \& Kadar, 2016). Kemampuan perempuan berdikari diukur dari beberapa faktor, seperti, kemampuan pemenuhan ekonomi melalui pemanfaatan berbagai sumber daya, tingkat pendidikan, kemampuan memimpin (leadership), jaringan sosial yang dibangun, dan lain sebagainya.

Keberadaan teknologi digital dengan berbagai aplikasinya merupakan sarana aktualisasi bagi perempuan yang berdikari khususnya berdaya secara ekonomi (Ayu, 2017; Isyfi'afiani, 2018). Menurut Utami (2019) salah satu efek positif dari perubahan teknologi adalah meningkatnya inklusi keuangan bagi perempuan. Lebih lanjut Dewi (2020) menyatakan bahwa perkembangan teknologi digital dan media sosial membantu perempuan untuk memberdayakan diri mereka sendiri baik di sektor politik, sosial, dan ekonomi. Karakteristik media sosial memungkinkan pengguna untuk berbagi informasi, berpartisipasi, berinteraksi, dan memodifikasi konten untuk membantu pemberdayaan perempuan. Beragam aplikasi media sosial dapat dimanfaatkan oleh perempuan untuk meningkatkan potensi diri dalam mewujudkan individu yang berdikari. Akses yang mudah dan murah, jangkauan media sosial yang luas, serta tawaran berbagai membuat aplikasi-aplikasi seperti Facebook, Twitter, Instagram, TikTok, dan lain sebagainya menjadi sarana representasi diri perempuan untuk berdikari khususnya untuk pengembangan bisnis dan perekonomian keluarga.

Hal ini pula yang terlihat dari Rachel Vennya. Berdasarkan tracking dan analisis postingan yang ada, Rachel Vennya memanfaatkan kehadiran media sosial bukan hanya sekedar menunjukkan eksistensi dengan unggahan foto yang ada, melainkan juga dimanfaatkan sebagai sarana pengembangan bisnis. Sebagai seorang womenpreneur, Rachel Vennya memiliki banyak sektor bisnis. Di bidang kuliner, Rachel Vennya memiliki brand Sate Taichan, Rumah Sedep, dan Lokasaji. Bahkan Sate Taichan masuk dalam nominasi Best Partner GoFood dari PT. Gojek Indonesia tahun 2018. Di bidang fashion, Rachel Vennya memiliki brand seperti Mahika Kids, Velthemodest, dan Raven Is Odd.

Rachel Vennya juga mengembangkan sayap bisnisnya ke bidang properti dengan membangun sebuah vila di Bandung yang masih dalam tahap pengerjaan dan ditargetkan akan selesai tahun 2021 yang diberinama Eudaimonia Studio. Rachel juga diketahui memiliki usaha di bidang Key Opinion Leader Management, yakni, sebuah manajemen yang menaungi para selebgram yang berfungsi untuk meng-handle kerjasama dengan brand-brand, sehingga cara kerja mereka diharapkan lebih profesional dan tepat sasaran. Dari semua lini bisnisnya tersebut, Rachel Vennya memiliki omset ratusan juta rupiah.

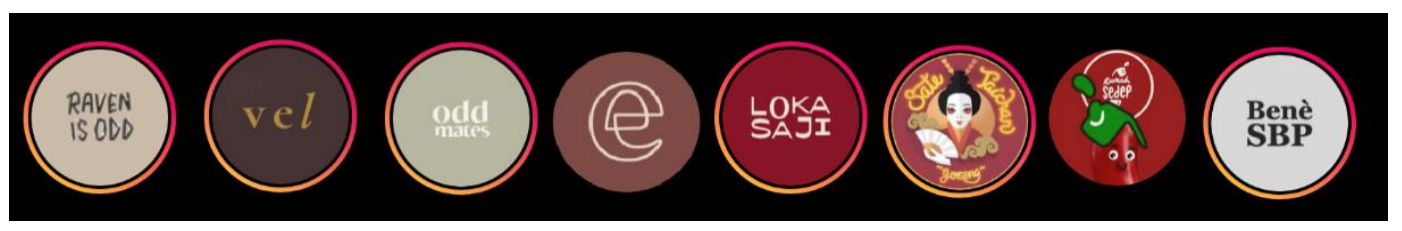

Sumber: Instagram @Rachelvennya

Gambar 2. Unit Bisnis Rachel Vennya 
Laiknya sebagai seorang influencer dengan jumlah pengikut 5,3 juta, Rachel Vennya juga membuka jasa endorsement bagi berbagai produk khususnya yang diproduksi oleh local brand. Dalam melakukan endorse, Rachel cukup selektif barang yang akan di-endorse. Dalam mengemas video maupun foto untuk meng-endorse sebuah produk, Rachel melakukannya dengan profesional. Untuk satu produk, Rachel tidak jarang menggunakan jasa makeup artist, menggunakan fotografer pribadi, serta menyediakan spot khusus utuk endorse di rumahnya agar kontennya terlihat lebih menarik. Hasil profesionalisme Rachel ini berhasil membantu peningkatan penjualan produk yang di-endorse-nya.

Apa yang dilakukan oleh Rachel Vennya dalam hal pemanfaatan media sosial (digital) untuk membangun usaha bisnisnya merupakan sebuah bentuk optimalisasi sektor ekonomi di era digital. Hal ini sejalan dengan argumentasi Tapscott (2014) kehadiran teknologi digital membuka peluang baru bagi siapa saja baik individu maupun perusahaan untuk meningkatkan penjualan dan

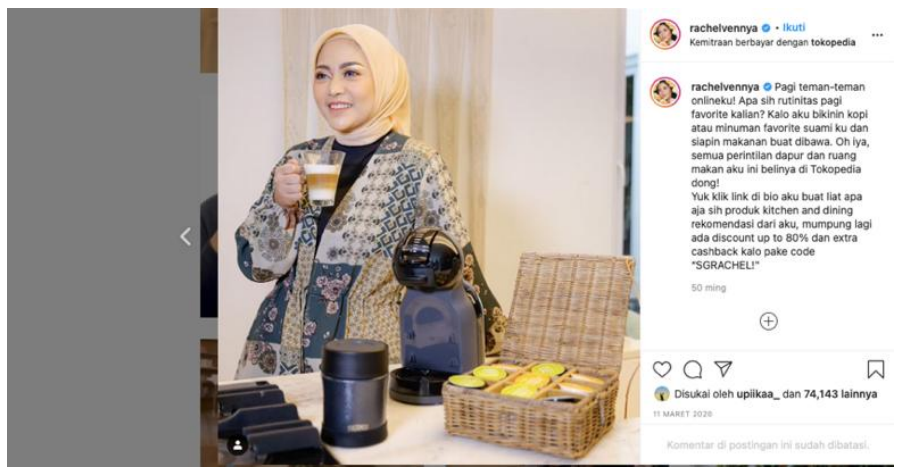

perekonomian mereka. Kemunculan media sosial mengubah secara radikal cara perusahaan dan individu terhubung dengan "pasar" dan kosumennya (Aral et al., 2013). Media sosial menciptakan dunia baru bagi produksi dan operasionalisasi kegiatan ekonomi. Para produsen dan pemasa dapat lebih mudah menjangkau konsumen mereka karena preferensi, latar belakang, dan prediksi permintaan dapat dikelola melalui data-data yang ada (Fisher, 2015).

Sumber: Instagram @Rachelvennya

Gambar 3. Rachel Vennya meng-engdorse salah satu produk (11 Maret 2020)

Kemunculan influencer merupakan fenomena baru dalam jagat digital. Aplikasi media sosial memungkinkan orang-orang untuk terkenal karena kreatifitas atau pun karena skandal yang mereka buat. Jumlah pengikut di akun media sosial memiliki pengaruh pada terbentuknya micro-selebrity ini. Dengan metode influencer marketing, produsen dan perusahaan dapat mengoptimalisasikan promosi produk mereka kepada konsumen potensial (Jin et al., 2019). Martínez-López et al. (2020) mengatakan bahwa penggunaan influencer dalam pemasaran produk merupakan upaya untuk mendorong tanggapan, sikap, dan perilaku yang positif pada pengikut mereka (konsumen) mengenai minat merek dengan menggunakan postingan yang dibagikan di platform tersebut. Di sisi lain memungkinkan influencer dan pengikut untuk berpartisipasi dalam pembuatan bersama citra merek di media sosial. Mereka yang menjadi pengikut micro-celebrity di akun media sosial cenderung akan membeli produk yang diiklankan oleh idola mereka karena dorongan untuk memiliki bentuk tubuh, wajah, fashion, dan kehidupan yang sama seperti idola mereka di media sosial. Dalam kaitannya dengan penelitian ini, Rachel Vennya yang berlatar belakang istri dan ibu muda maka berfokus untuk meng-endorse produk-produk perawatan wajah, produk rumah tangga, paket liburan, produk anak-anak, dan lain sebagainya. Magnitude dari praktik endorsement ini sangat mungkin menjangkau followers Rachel Vennya yang kebanyakan juga perempuan usia remaja atau dewasa awal. 


\subsection{Perempuan dan Pendidikan}

Aspek representasi perempuan berdaya selanjutnya adalah aktualisasi diri dalam bidang pendidikan. Hasil analisis terhadap postingan @ Rachelvennya mendapati bahwa meskipun telah menjelma sebagai pengusaha yang sukses, pendidikan masih menjadi prioritas Rachel Vennya. Hal ini ditunjuukan dalam postingan tanggal 15 Oktober 2019, dimana Rachel Vennya dan suaminya Muhammad Niko Al Hakim mampu menyelesaikan studi Sarjana Ilmu Komunikasi pada London School of Public Relations (LSPR).

Rachel Vennya mengakui bahwa upaya menyelesaikan studi di tingkat sarjana penuh dengan perjuangan, terlebih ia harus mampu menyeimbangkan peran kesehariannya. Rachel Vennya berhasil menjadi Sarjana Ilmu Komunikasi dari LSPR meskipun dalam usia kehamilan 32 (tiga puluh dua) minggu. Sebagai influencer dan womenpreneur, Rachel Vennya mendapatkan beasiswa

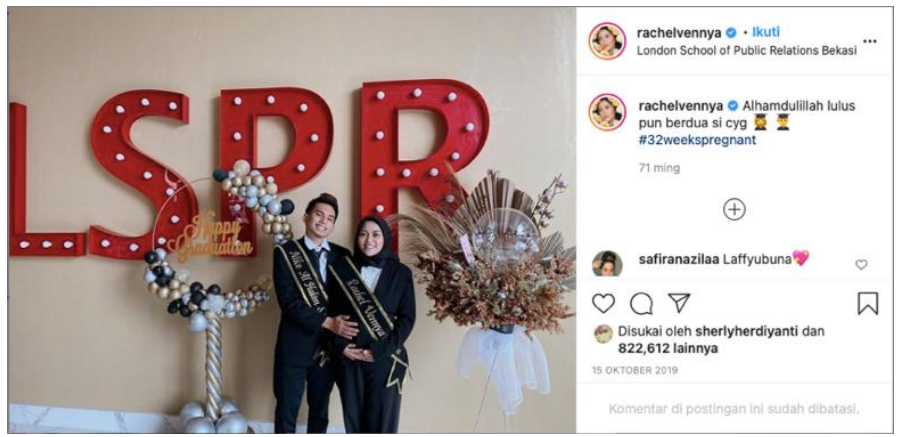

dari LSPR untuk melanjutkan studi jenjang Magister Performing Arts. Menyeimbangkan antara kehidupan keluarga, dunia usaha, dan pendidikan tentu tidak mudah, mengingat semua hal tersebut perlu mendapat prioritas. Hal ini sejalan dengan apa yang dikatakan oleh (Mungunsong, 2009) bahwa keluarga dan lingkungan yang mendukung menjadi faktor utama bagi seorang perempuan untuk berkembang tanpa harus meninggalkan peran lainnya.

Sumber: Instagram @Rachelvennya

Gambar 4. Rachel Vennya dan Suaminya Menyelesaikan Studi di LSPR (15 Oktober 2019)

Sebagai influencer dan pengusaha yang sukses, Rachel Vennya juga aktif dalam kegiatan kemasyarakatan dengan berbagi ilmu, kiat, dan motivasi baik kepada semasa perempuan maupun anak-anak. Hal ini terlihat dalam beberapa unggahan foto di feed Instagramnya. Dalam setiap seminar yang dihadirinya sebagai pembicara, Rachel Vennya sering berbicara tentang topik kesehatan mental bagi perempuan usia remaja dan dewasa awal serta topik terkait pentingnya solidaritas sosial di kalangan milenial. Dalam caption foto di sebuah acara yang digagas oleh Sublime ID di Makassar, Rachel Vennya mengisyaratkan bahwa sebagai influencer sudah menjadi tanggungjawabnya untuk berbagi berbagai hal kepada orang lain. Rachel Vennya menulis:

"Success isn't about how much money you make, it's about the difference you make in people's lives" -Michelle Obama. Walaupun banyak banget yang meremehkan "Influencer" dan walaupun aku gak pernah bilang diri aku ini "Influencer" atau "selebgram" (karena menurutku itu kalian yg menilai bukan aku mengaku2 sendiri) tapi aku gak bisa menghindar kalau kata2 itu sudah ada di mindset orang2 kalo lihat aku, hal ini aku jadikan kesempatan untuk sharing tentang passion aku, hal yg benar2 aku kerjakan dari nol yaitu menjadi "entrepreneur", pengalamanku dan kisah hidup aku di bidang bisnis. Semoga sharing kali ini bisa menginspirasi walaupun hanya setitik, maaf kalau banyak yg kurang ? love Makassar! Thankyou@sublime id! (Unggahan 9 Maret 2019).

Saat tsunami melanda Banten dan Lampung, Rachel Vennya memulai tagar \#OrangBaik untuk menggalang dana. Selain menggalang dana bagi korban bencana, Rachel juga memberikan motivasi kepada anak-anak penyintas tsunami seperti terlihat dalam unggahannya pada 18 Januari 

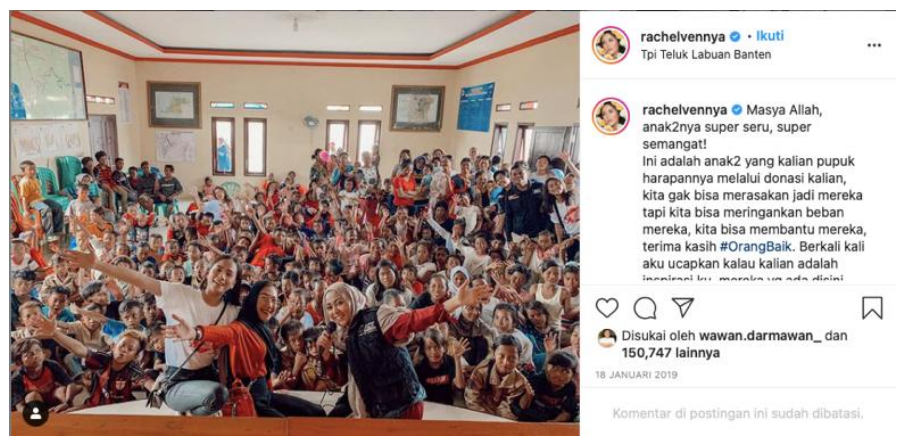

2019. Keberadaan sukarelawan seperti social media influencer dapat mengurangi tekanan psikologis bagi pada penyintas bencana (Schlegelmilch et al., 2020). Mereka yang datang membantu dapat menumbuhkan harapan untuk bangkit dan memberi pelajaran berharga bagi para penyintas baik orang dewasa maupun anak-anak.

Sumber: Instagram @Rachelvennya

Gambar 5. Rachel Vennya Memberi Motivasi Kepada Anak-Anak Penyintas Tsunami Banten (18 Januari 2019)

\subsection{Perempuan Juga Mampu Memimpin}

Peran sebagai influencer sepertinya tidak menjadikan Rachel Vennya lupa diri. Hal ini terbukti dari kepeduliaannya kepada sesama. Berdasarkan rasa kemanusiaan ini, Rachel Vennya menjadi fenomena tersendiri. Saat pandemi Covid-19 melanda dunia termasuk Indonesia (bbc.com, 2020), Rachel membuka donasi \#OrangBaik melalui situs Croudfunding Kitabisa.com. Memanfaatkan jaringan dan pengaruh yang dimilikinya, Rachel dapat mengumpulkan donasi untuk membantu penyediaan Alat Perlindungan Dasar (APD) bagi tenaga medis yang berjuang dalam penanganan pandemi serta membantu orang-orang kelas menengah ke bawah yang terdampak pandemi. Rachel Vennya mampu menggalang dana Rp2 miliar dalam satu hari.

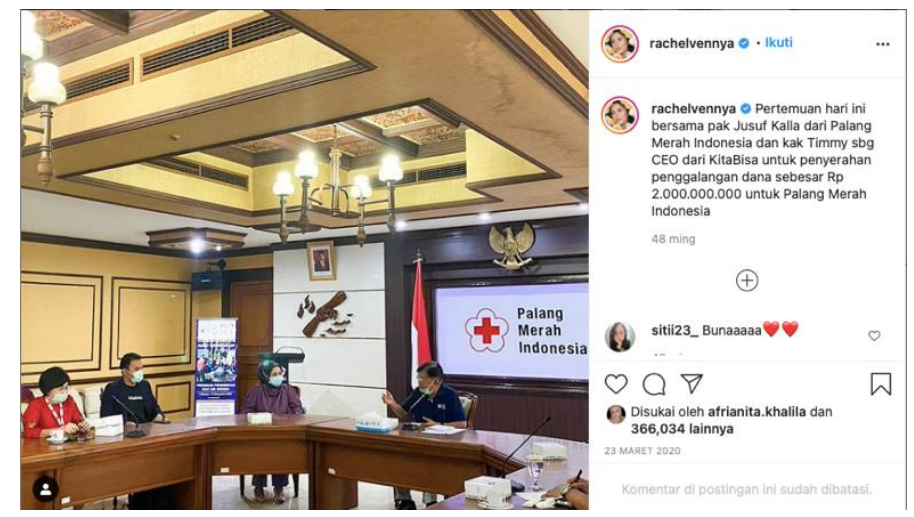

Sumber: Instagram @Rachelvennya

Gambar 6. Rachel Vennya Menyerahkan Donasi kepada PMI (23 Maret 2020)

Hingga akhirnya donasi itu ditutup, Rachel berhasil mengumpulkan lebih lebih dari 135 ribu orang baik untuk berpartisipasi dalam aksi kemanusiaan ini. Angka yang dikumpulkan pun tidak sedikit, yakni menyentuh 9 milyar hanya dalam kurun waktu kurang dari 2 minggu saja. Sebuah angka yang terbilang cukup fantastis untuk sebuah penggalangan dana terlebih hal ini diinisiasikan bukan oleh sebuah perusahaan besar, melaikan seorang selebgram. Pencapaian ini seolah membuktikan bahwa Rachel layak diposisikan sebagai opinion leader (Jain \& Katarya, 2018; Rehman et al., 2020) dan bahkan ia cenderung lebih berpengaruh daripada selebritis ataupun pemain sinetron sekalipun. Atas pencapaiannya dalam menghimpun dana kemanusiaan dengan 
jumlah terbanyak ini, Rachel bahkan sempat diwacanakan untuk diberikan penghargaan oleh Museum Rekor Indonesia (MURI) pada April 2020 lalu. Akan tetapi hal ini ditolak olah Rachel, menurutnya yang layak mendapatkan apresisasi sesungguhnya bukan dia melaikan para donator dan para penerima bantuan yakni para petugas medis.

\subsection{Perempuan Berhak Berekspresi}

Sebagai seorang perempuan, sudah fitrahnya Rachel Vennya sangat memperhatikan penampilannya. Bahkan sejak ia mengenakan hijab di tahun 2019, Rachel dengan gaya hijabnya yang santai dan tetap stylish menjadi salah satu fashion icon di Indonesia. Dalam unggahannya, Ia kerap menampilkan outfit of the day yang mampu menyita perhatian banyak orang dan menginspirasi followers-nya di Instagram. Bahkan gaya hijab clean anti-badai miliknya diikuti oleh sederet selebgram lain. Hal yang membuat Rachel Vennya berbeda dari selebgram lain adalah tidak menonjolnya hedonisme dalam setiap unggahannya (Putri, 2018).

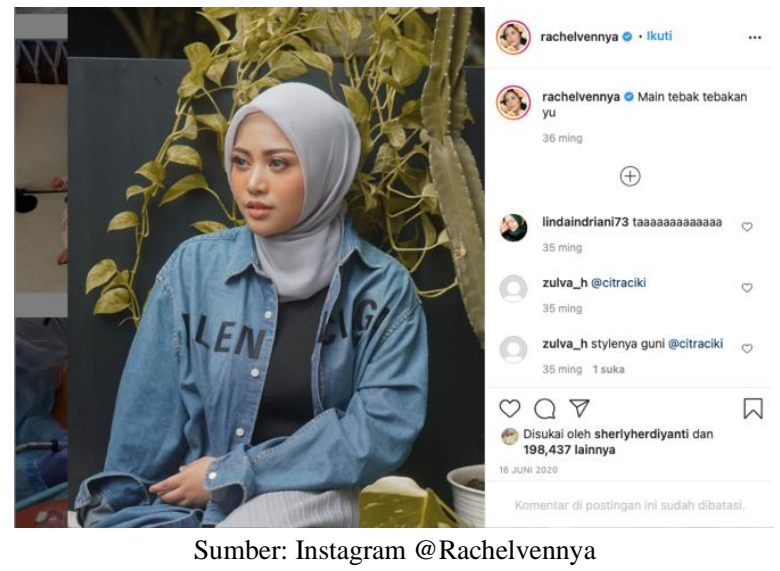

Gambar 7. Outfit of the Day Rachel Vennya (23 Maret 2020)

Selain mengunggah foto koleksi fashion-nya, Rachel Vennya juga terlibat dalam aksi kepedulian kepada sesama perempuan. Hal ini terlihat dalam unggahannya pada 8 Maret 2020 saat Rachel ikut aksi Mowen's March (WM) atau hari perempuan se-dunia. Aksi peringatan WM ini dimaksudkan sebagai gerakan moral bersama sebagai bentuk solidaritas untuk memperjuangkan hak-hak perempuan. Unggahan Rachel Vennya ikut aksi WM ini disukai oleh 519.982 pengikutnya dan mendapat respon positif di kolom komentarnya. Hal ini membuktikan bahwa posisi sebagai instafamous tidak membuat Rachel Vennya berada pada kutub yang terpisah dengan isu-isu kaumnya. Dengan kehadiran Rachel Vennya dan para influencer lain serta pengaruh dari jangkauan media sosial yang luas, berdampak pada kesadaran publik untuk peduli pada isu-isu kemanusiaan di sekitar mereka (Caldeira et al., 2020b; Khamis et al., 2017; Kostygina et al., 2020).

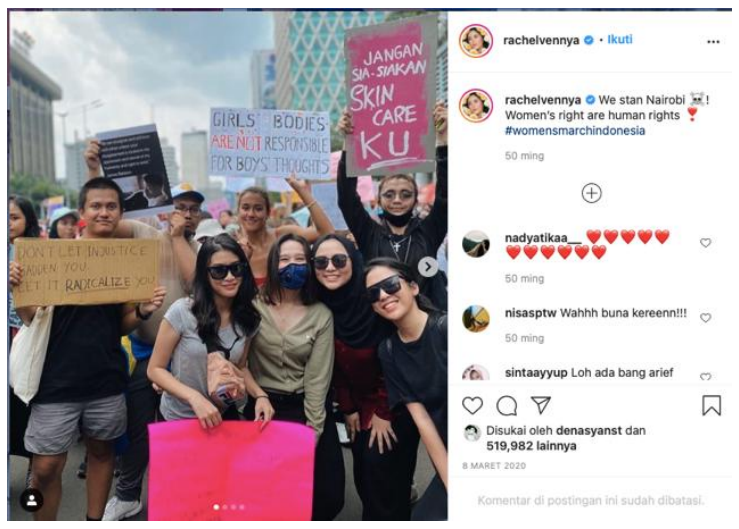




\section{Sumber: Instagram @Rachelvennya \\ Gambar 8. Rachel Vennya Ikut Gerakan Women's March (8 Maret 2020)}

\subsection{Keluarga di Atas Segalanya}

Di tengah kesibukannya mengelola kerajaan bisnisnya, Rachel selalu menyempatkan waktu untuk keluarga kecilnya. Rachel memiliki sebuah mimpi untuk membangun rumah untuk kedua anaknya, impian itu dia beri tagar \#RumahUntukXabiru dan \#RumahUntukChava. Hal ini ia lakukan agar ia lebih bersemangat dan memiliki tujuan yang jelas dalam bekerja. Ia mengumpulkan pundi-pundi uang yang dihasilkannya dari bisnis dan endorse-nya untuk mewujudkan mimpi itu. Akhirnya, di tahun 2018 Rachel berhasil membangun rumah pertamanya yang didesain sesuai dengan keinginannya. Di akhir tahun 2020, Rachel diketahui membeli rumah keduanya. Atas pencapaiannya tersebut, sekali lagi Rachel membuktikan bahwa ia sangat passionate dalam mewujudkan mimpinya satu persatu.

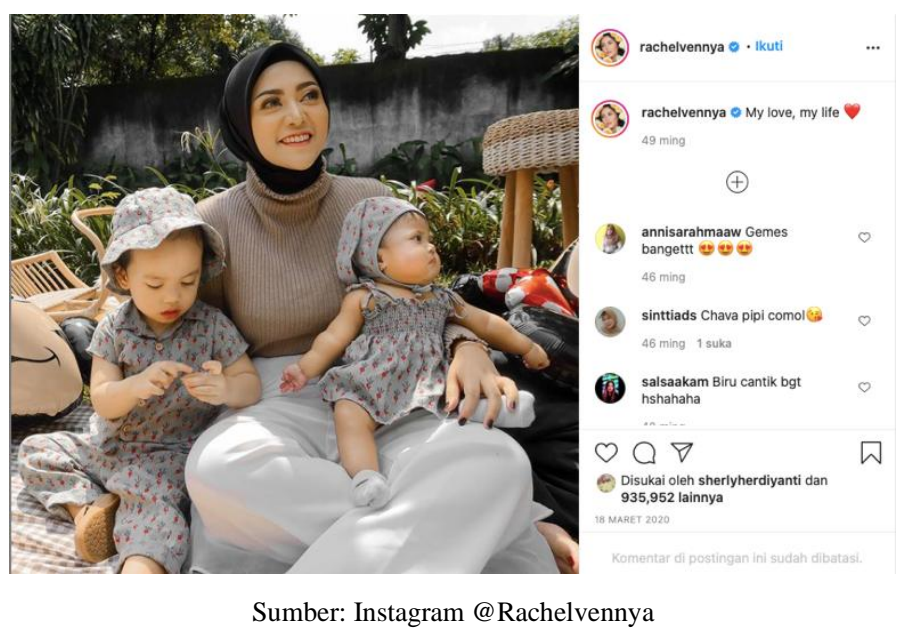

Gambar 9. Rachel Vennya dan Kedua Anaknya (18 Maret 2020)

Berbicara tentang anak, dalam beberapa postingan di laman instagramnya, Rachel bahkan tidak segan membagikan tips parenting tentang bagaimana cara dia mendidik kedua anaknya. Rachel selalu mengajarkan buah hatinya untuk menjadi pribadi yang sopan dan penyayang. Hal ini dibuktikan dari tingkah laku anak sulungnya, Xabiru yang selalu menunjukkan rasa sayang kepada adik perempuannya di usianya yang bahan belum genap 4 tahun. Atas tingkah lakunya yang menggemaskan itu, Xabiru bahkan mendapat panggilan sebagai anak online oleh netizen. Kesuksesan Rachel dalam mendidik anaknya menjadi sebuah inspirasi tersendiri bagi follower-nya karena di era sekarang ini tentu sangat sulit untuk mengajarkan anak-anak untuk bersikap demikian. Praktis, Rachel menjelma menjadi role model bagi ibu-ibu muda masa kini. Selain sukses di dunia bisnis, Rachel juga membuktikan bahwa ia berhasil mendidik anaknya.

Melalui telaah atas unggahan konten-konten yang terdapat dalam akun Instagram @ Rachelvennya yang telah dipaparkan pada bagian sebelumnya, menunjukkan bahwa di era digital ini perempuan memiliki peluang dan kesempatan yang tidak terbatas untuk dapat mengepakkan sayapnya (Caldeira et al., 2018; Dodson, 2015; Rettberg, 2018). Bukan berasal dari kalangan selebritis yang dikenal melalui modelling, video musik, film layar lebar, ataupun bintang sinetron. Rachel Vennya adalah murni sosok perempuan biasa yang piawai memanfaatkan gawainya dalam menemukan, mengevaluasi, memproduksi, serta mengkomunikasikan passion dan potensi yang dimilikinya melalui gambar, tulisan maupun bentuk pesan lain. 
Di sela-sela kesibukannya menjadi seorang Istri dan Ibu bagi kedua anaknya, Rachel Vennya menunjukkan bahwa ia tetap bisa aktif dan menginspirasi melalui beragam kegiatan. Rachel Vennya mendobrak realitas atas anggapan ketidakberdayaan kaum perempuan yang selama ini selalu diposisikan sebagai pekerja domestik sehingga tidak dapat berkontribusi secara aktif di sektor publik (Duffy \& Hund, 2015; Saputri \& Himam, 2015). Dengan berbagai kreativitas serta persentasi diri, Rachel Vennya membangun persona atas dirinya sebagai figur yang dicintai oleh khalayak luas. Berbekal popularitas yang dapat dilihat dari jumlah respon seperti like dan komentar yang tinggi, Rachel Vennya kemudian dianggap memiliki pengaruh tinggi terhadap khalayaknya dan tidak berlebihan jika kemudian ia diposisikan sebagai sosok role model bagi kaum perempuan.

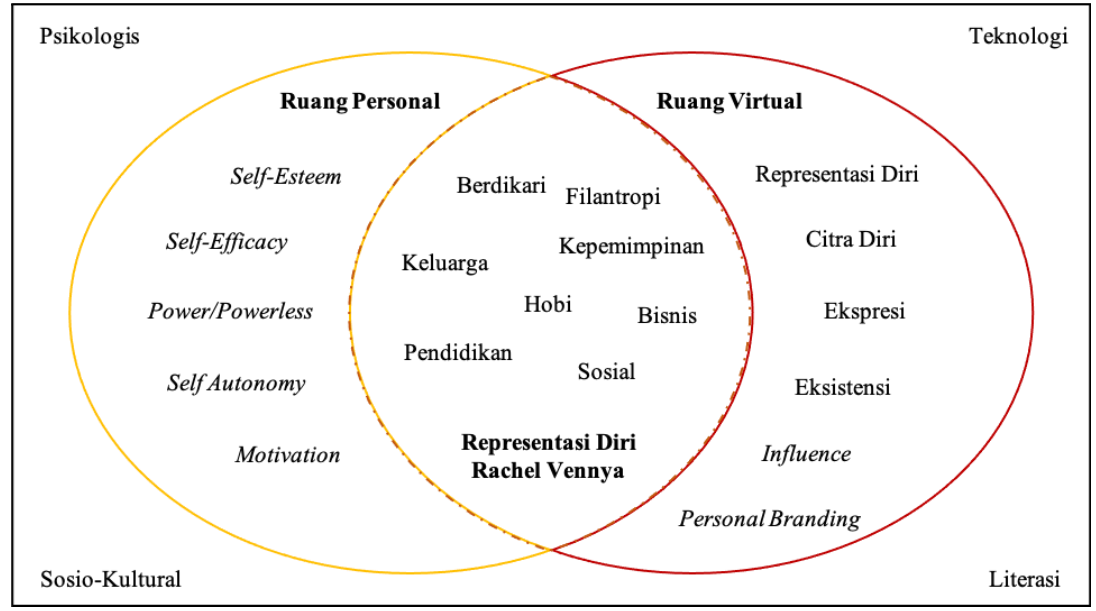

Sumber: Hasil Analisis Penelitian

Gambar 10. Relasi Ruang Personal \& Ruang Virtual Perempuan Berdaya

Gambar 10 di atas merupakan tawaran relasi antara ruang personal dan ruang virtual dalam kaitannya dengan representasi perempuan berdaya. Digitalisasi membuka ruang baru bagi partisipasi perempuan dan memungkinkan mereka untuk keluar dari lingkaran setan yang selama ini mengungkung khususnya bagi perempuan dari negara-negara dunia ketiga. Digitalisasi memungkinkan setiap perempuan untuk mengembangkan kewirausahaan mereka untuk menolong dirinya sendiri atau pun keluarganya (Ughetto et al., 2020). Melalui teknologi digital, perempuan dapat meningkatkan pendidikannya, belajar sesuatu yang baru dari berbagai platform virtual. Dari sisi ekonomi, pemanfaatan media digital yang efektif dapat membantu perempuan untuk berwirausaha (Duffy \& Hund, 2015; Duffy \& Pruchniewska, 2017). Mereka dapat mengunggah berbagai hasil kerajinan tangan dan produksi rumah tangga sehingga dapat menjangkau konsumen yang lebih luas (Rachmansyah \& Supratman, 2020).

Di dalam era digital, ruang personal dan ruang virtual berada dalam satu irisan besar dan sulit dipisahkan. Anggapan bahwa ruang virtual merupakan replikasi dari ruang personal di dunia nyata barangkali tidak sepenuhnya salah. Meski pun anggapan tersebut tidak dapat sepenuhnya diterima karena interaksi di dunia nyata tidaklah sama persis dengan interaksi dalam dunia digital. Terlepas dari perdebatan tersebut, riset ini menemukan bahwa ruang personal di dunia nyata dengan ruang virtual dapat dimaksimalkan untuk membuat perempuan mandiri. Ada beberapa faktor yang menurut peneliti berpengaruh, yaitu kepercayaan diri, efikasi diri, kekuatan/kemampuan, otonomi, dan motivasi (Bt Mahmud et al., 2019; Peterson et al., 2008; Supratman, 2012).

Di sisi lain keterbukaan akses teknologi juga menjadi faktor penting untuk meningkatkan literasi perempuan. Ruang virtual dimanfaatkan oleh perempuan untuk mengekspresikan hal-hal yang mungkin tidak mereka lakukan di dunia nyata. Ekpos yang besar menjadikan banyak perempuan tertarik untuk masuk ke dalam media digital. Dalam media sosial, eksistensi individu 
ditentukan oleh seberapa banyak pengikutnya. Di satu sisi, jumlah pengikut yang banyak dapat dimanfaatkan untuk mendukung gagasan yang bersifat positif. Seperti yang dilakukan Rachel Vennya yang menghimpun dana bersama dengan para pengikutnya. Di sisi lain jumlah pengikut ini juga rentan terhadap tindakan negatif seperti perundungan siber. Oleh karenanya, di era digital sangat diperlukan literasi sebagai kecakapan yang berguna sebagai panduan bagi pengguna media sosial (Rahmadi \& Hayati, 2020)

\section{PENUTUP}

Kemajuan teknologi digital telah mengubah wajah dunia serta menghadirkan peluang baru bagi perempuan. Media sosial seolah menjadi ruang publik baru bagi perempuan dalam upaya mengaktualisasikan dan merepresentasikan dirinya. Peluang inilah yang berhasil dimanfaatkan oleh Rachel Vennya yang kemudian mejadikannya sebagai representasi perempuan berdaya yang tidak hanya terampil di area domestik, tetapi juga berpeluang menjadi inspirator dan pemimpin di era digital. Riset ini berkesimpulan bahwa kepiawaian Rachel Vennya dalam menghasilkan kontenkonten yang menginspirasi pada laman jejaring Instagram pribadinya, menjadi sebuah sinyal bahwa eksistensi perempuan di sektor publik patut diperhitungkan. Rachel Vennya membuktikan bahwa perempuan berhak menjadi berdaya dengan caranya sendiri.

Rachel Vennya adalah sebuah representasi atas kaum perempuan yang berhasil menembus era digital, bersaing melompati tembok penghalang yang selama ini terlanjur terbangun tinggi di tengah masyarakat, dan bukan hanya tunduk pasrah pada kerasnya kemajuan zaman. Eksistensi Rachel Vennya di panggung Instagram menjadi bukti bahwasanya perempuan juga dapat menentukan bagaimana cara mengaktualisasikan diri dan memilih pekerjaan serta meningkatkan kapasitasnya untuk meniti jenjang karir lebih tinggi. Rachel Vennya memberikan gambaran bahwa perempuan harus berani mewujudkan mimpinya dengan melakukan beragam aktivitas yang ia sukai tanpa harus meninggalkan kodratnya sebagai seorang ibu, istri, atau bahkan anak.

Hasil riset memberikan kontribusi bagi pengembangan kajian feminisme di era digital khususnya dalam aspek perempuan berdaya. Isu-isu feminisme selalu menjadi hal menarik untuk dikaji terlebih dalam kaitannya dengan konstruksi sosial dan media. Selama ini lingkungan sosial dan media selalu tidak pernah adil merepresentasikan perempuan. Perempuan dicitrakan lemah dan menjadi victim subsider bagi ilusi imajiner kaum laki-laki (Supratman, 2012). Media sosial dapat menjadi saluran perjuangan baru bagi feminisme di tengah ketidakadilan konstruksi media yang berbasis pada maskulinitas. Melalui media sosial, perempuan dapat menjalin sosialisasi yang lebih luas, membangun basis pengaruh kepada para pengikutnya, menghimpun solidaritas sosial, mengekspresikan gagasan dan opini mereka, serta meningkatkan perekonomiannya. Hal yang tidak kalah penting adalah perlunya kedewasaan psikologis dan nalar kritis perempuan untuk mengontrol perilaku mereka bermedia sosial sehingga tidak hanya terjebak untuk mencari eksistensi saja.

Hasil penelitian ini sangat mungkin bersifat subjektif oleh karena keterbatasan ruang lingkup, objek, dan metode penelitian. Oleh karenanya, diperlukan data pembanding yang lebih luas dengan topik kajian seputar perempuan di era digital. Selain itu, perlu pula penggunaan teori dan metode riset lainnya guna membedah representasi perempuan di era digital sehingga kajian yang dihasilan lebih komprehensif.

\section{Ucapan Terimakasih}

Terima kasih kepada berbagai pihak yang telah membantu terlaksananya riset dan publikasi ini. Terima kasih kepada Redaksi dan Reviewer Jurnal Studi Komunikasi dan Media (JSKM) BPSDMP Kominfo yang telah banyak membantu sehingga artikel ini dapat dipublikasikan. 


\section{DAFTAR PUSTAKA}

An Nur, F., \& Hariyanti, N. (2019). Beauty Vlogger: Representasi Perempuan di Era Disrupsi. ETTISAL : Journal of Communication, 4(2), 213. https://doi.org/10.21111/ejoc.v4i2.3600

Aral, S., Dellarocas, C., \& Godes, D. (2013). Social media and business transformation: A Framework for research. Information Systems Research, 24(1), 3-13. https://doi.org/10.1287/isre.1120.0470

Atmoko, B. D. (2012). Instagram Handbook. Media Kita.

Ayu, R. K. (2017). Perempuan Pebisnis Startup di Indonesia dalam Perspektif Cybertopia. Jurnal Studi Komunikasi (Indonesian Journal of Communications Studies), I(2), 116-130. https://doi.org/10.25139/jsk.v1i2.167

bbc.com. (2020). Virus corona: Jokowi umumkan langkah pengendalian Covid-19, tapi tanpa "komando nasional." https://www.bbc.com/indonesia/indonesia-51897307\#orb-banner

Belinska, S. (2018). REPRESENTATION OF WOMAN'S BODY ON INSTAGRAM : Qualitative Content Analysis of the year 2018 posts of top fitness influencer Michelle Lewin [Örebro University]. http://www.diva-portal.org/smash/record.jsf?pid=diva2\%3A1223803\&dswid=-9530

Best, C. (2016). Narcissism or self-actualization? An evaluation of 'selfies' as a communication tool. In D. S. Coombs \& S. Collister (Eds.), Debates for the Digital Age: The Good, The Bad, and the Ugly of Our Onine World (1st ed., pp. 55-76). Praeger.

Bouvier, G. (2012). How Facebook users select identity categories for self-presentation. Journal of Multicultural Discourses, 7(1), 37-57. https://doi.org/10.1080/17447143.2011.652781

Brophy, J. E. (2010). Developing a corporeal cyberfeminism: Beyond cyberutopia. New Media and Society, 12(6), 929-945. https://doi.org/10.1177/1461444809350901

Bt Mahmud, M., Bazilah Bt Mohd Zain, N. A., \& Firdaus Bt Fatah Yasin, R. (2019). Participation of Muslim Women in Islamic Philanthropy in Digital Era: Malaysian Experience. Afkaruna, 15(2), 165-187. https://doi.org/10.18196/aiijis.2019.0101.165-186

Caldeira, S. P. (2016). Identities in flux: An analysis to photographic self-representation on instagram. Observatorio, 10(3), 135-158. https://doi.org/10.15847/obsobs10320161031

Caldeira, S. P., De Ridder, S., \& Van Bauwel, S. (2020a). Between the mundane and the political: women's self-representations on Instagram. Social Media and Society, 6(3). https://doi.org/10.1177/2056305120940802

Caldeira, S. P., De Ridder, S., \& Van Bauwel, S. (2020b). Between the Mundane and the Political: Women's Self-Representations on Instagram. Social Media and Society, 6(3). https://doi.org/10.1177/2056305120940802

Caldeira, S. P., Van Bauwel, S., \& Ridder, S. De. (2018). A Different Point of View: Women's Selfrepresentation in Instagram's Participatory Artistic Movements @girlgazeproject and @ arthoecollective. Critical Arts, 32(3), 26-43. https://doi.org/10.1080/02560046.2018.1447592

Daniels, J. (2013). Rethinking cyberfeminism(s): Race, gender, and embodiment. Women, Science, and Technology: A Reader in Feminist Science Studies, 37(1), 353-369. https://doi.org/10.4324/9780203427415-33

Dewi, A. S. (2020). Investigating the Impact of Instagram on Women Entrepreneurs' Empowerment. 452(Aicosh), 58-61. https://doi.org/10.2991/assehr.k.200728.013

Dewi, I. A. A. (2019). Catcalling: Candaan, Pujian atau Pelecehan Seksual. Acta Comitas: Jurnal Hukum Kenotariatan, 4(2), 198-212. https://doi.org/https://doi.org/10.24843/AC.2019.v04.i02.p04.

Djafarova, E., \& Trofimenko, O. (2019). 'Instafamous'-credibility and self-presentation of micro-celebrities on social media. Information Communication and Society, 22(10), 1432-1446. https://doi.org/10.1080/1369118X.2018.1438491

Dodson, A. S. (2015). Postfeminist Digital Culture: Femininity, Social Media and Self-Representation. Palgrave Macmillan.

Duffy, B. E., \& Hund, E. (2015). "Having it All" on Social Media: Entrepreneurial Femininity and SelfBranding Among Fashion Bloggers. Social Media and Society, 1(2). https://doi.org/10.1177/2056305115604337

Duffy, B. E., \& Pruchniewska, U. (2017). Gender and self-enterprise in the social media age: a digital double bind. Information Communication and Society, 20(6), 843-859. https://doi.org/10.1080/1369118X.2017.1291703

Dy, A. M., Marlow, S., \& Martin, L. (2017). A Web of opportunity or the same old story? Women digital entrepreneurs and intersectionality theory. Human Relations, 70(3), 286-311. https://doi.org/10.1177/0018726716650730

Enli, G., \& Thumim, N. (2012). Socializing and Self-Representation online: Exploring Facebook. Observatorio $\left(O B S^{*}\right), 6(1), 87-105$. https://doi.org/10.7458/obs612012489

Fahrimal, Y. (2018). Netiquette: Etika Jejaring Sosial Generasi Milenial Dalam Media Sosial. Jurnal 
Penelitian Pers Dan Komunikasi Pembangunan, 22(1), 69-78. https://doi.org/10.46426/jp2kp.v22i1.82

Fisher, E. (2015). 'You Media': audiencing as marketing in social media. Media, Culture and Society, 37(1), 50-67. https://doi.org/10.1177/0163443714549088

Gajjala, R., \& Wauthier, K. (2020). Feminized Digital Sociality and Online Philanthropy. Second International Handbook of Internet Research, 225-237. https://doi.org/10.1007/978-94-024-1555-1_58

Graneheim, U. H., Lindgren, B. M., \& Lundman, B. (2017). Methodological challenges in qualitative content analysis: A discussion paper. Nurse Education Today, 56(May), 29-34. https://doi.org/10.1016/j.nedt.2017.06.002

Handayani, F., \& Adelvia, K. (2020). INSTAGRAM TOURISM: MENCIPTAKAN HYPE PADA DESTINASI WISATA (STUDI PADA AKUN @INDOFLASHLIGHT). Jurnal Studi Komunikasi Dan Media, 24(2), 105. https://doi.org/10.31445/jskm.2020.2856

Hendrickse, J., Arpan, L. M., Clayton, R. B., \& Ridgway, J. L. (2017). Instagram and college women's body image: Investigating the roles of appearance-related comparisons and intrasexual competition. Computers in Human Behavior, 74, 92-100. https://doi.org/10.1016/j.chb.2017.04.027

Hunsinger, J., Allen, M. M., \& Klastrup, L. (2020). Second International Handbook of Internet Research. In J. Hunsinger, M. M. Allen, \& L. Klastrup (Eds.), Second International Handbook of Internet Research. Springer Berlin Heidelberg. https://doi.org/10.1007/978-94-024-1555-1

Islami, A. nur. (2018). Instagram : Media Sosial Dan Ekistensi Diri Remaja Berprestasi Di Kota Palu. Jurnal Kinesik, 5(3), 6. https://jurnal.fisip.untad.ac.id/index.php/kinesik/article/view/57

Isyfi'afiani. (2018). Advancing Women's Digital Skills and Economic Empowerment through Girls in Tech Indonesia: A Case Study. SALASIKA: Indonesian Journal of Gender, Women, Child, and Social Inclusion's Studies, 1(1), 21-32. https://doi.org/https://doi.org/10.36625/sj.v1i1.39

Jain, L., \& Katarya, R. (2018). A Systematic Survey of Opinion Leader in Online Social Network. ICSNS 2018 - Proceedings of IEEE International Conference on Soft-Computing and Network Security, 1-5. https://doi.org/10.1109/ICSNS.2018.8573639

Jan, M., Soomro, S. A., \& Ahmad, N. (2017). Impact of Social Media on Self-Esteem. European Scientific Journal, ESJ, 13(23), 329. https://doi.org/10.19044/esj.2017.v13n23p329

Jin, S. V., Muqaddam, A., \& Ryu, E. (2019). Instafamous and social media influencer marketing. Marketing Intelligence and Planning, 37(5), 567-579. https://doi.org/10.1108/MIP-09-2018-0375

Karapanos, E., Teixeira, P., \& Gouveia, R. (2016). Need fulfillment and experiences on social media: A case on Facebook and WhatsApp. Computers in Human Behavior, 55, 888-897. https://doi.org/10.1016/j.chb.2015.10.015

Kertamukti, R., Nugroho, H., \& Wahyono, S. B. (2018). Komunikasi Visual: Fantasi Tubuh Wanita Kelas Menengah di Instagram. Jurnal Kajian Komunikasi, 6(2), 231. https://doi.org/10.24198/jkk.v6i2.17925

Khamis, S., Ang, L., \& Welling, R. (2017). Self-branding, 'micro-celebrity' and the rise of Social Media Influencers. Celebrity Studies, 8(2), 191-208. https://doi.org/10.1080/19392397.2016.1218292

Kosakoy, J. P. (2016). Representasi Perempuan Dalam Film "Star Wars VII: The Force Awakens." Jurnal EKomunikasi, 4(1), 1-12. http://publication.petra.ac.id/index.php/ilmu-komunikasi/article/view/4878

Kostygina, G., Tran, H., Binns, S., Szczypka, G., Emery, S., Vallone, D., \& Hair, E. (2020). Boosting Health Campaign Reach and Engagement Through Use of Social Media Influencers and Memes. Social Media and Society, 6(2). https://doi.org/10.1177/2056305120912475

Krebs, W. A. (2001). Collins Gem: Australian English Dictionary (Third Edit). Harper Collins Publisher.

Kuncoro, A., \& Kadar, K. (2016). Pengaruh Pemberdayaan Perempuan dan Peningkatan Sumberdaya Ekonomi Keluarga. BUANA GENDER : Jurnal Studi Gender Dan Anak, 1(1), 45. https://doi.org/10.22515/bg.v1i1.67

Kurniawati, J. (2020). Selfie : Mediatisasi Tubuh Perempuan Berjilbab Seksi Dalam Instagram. JURNAL SOSIAL : Jurnal Penelitian Ilmu-Ilmu Sosial, 21(1), 39-43. https://doi.org/10.33319/sos.v21i1.56

Kurniawati, J., Ahimsa-Putra, H. S., Irawanto, B., \& Noviani, R. (2019). Selfie Objectification: Representation Of Hijabed Women In Instagram. The 10th IGSSCI (International Graduate Students and Scholars' Conference in Indonesia) Page 166 NEW MEDIA AND THE CHANGING SOCIAL LANDSCAPE OF CONTEMPORARY SOCIETIES: How Are New Media Reshaping the Whole Aspects of Life Ofcontemporary Societies?, 166-180. https://doi.org/10.18502/kss.v3i20.4934

Lestari, N., Fadilah, A. N., \& Wuryanta, E. W. (2020). Empowered Women \& Social Media: Analyzing \#YourBeautyRules in Cyberfeminism Perspective. Jurnal ASPIKOM, 5(2), 280. https://doi.org/10.24329/aspikom.v5i2.664

Mahendra, B. (2017). Eksistensi Sosial Remaja Dalam Instagram (Sebuah Perspektif Komunikasi). Jurnal Visi Komunikasi, 16(1), 151-160.

Martínez-López, F. J., Anaya-Sánchez, R., Fernández Giordano, M., \& Lopez-Lopez, D. (2020). Behind influencer marketing: key marketing decisions and their effects on followers' responses. Journal of 
Marketing Management, 36(7-8), 579-607. https://doi.org/10.1080/0267257X.2020.1738525

Masse, M. R. (2017). NETWORK SOCIETY, INTERNET, DAN AKTIVITAS KOMUNIKASI MASYARAKAT. Jurnal Studi Komunikasi Dan Media, 21(2), 165-180. https://doi.org/10.31445/jskm.2017.210203

McAdam, M., Crowley, C., \& Harrison, R. T. (2020). Digital girl: cyberfeminism and the emancipatory potential of digital entrepreneurship in emerging economies. Small Business Economics, 55(2), 349362. https://doi.org/10.1007/s11187-019-00301-2

Mehdizadeh, S. (2010). Self-presentation 2.0: Narcissism and self-esteem on facebook. Cyberpsychology, Behavior, and Social Networking, 13(4), 357-364. https://doi.org/10.1089/cyber.2009.0257

Milrod, D. (2002). The concept of the self and the self representation. Neuropsychoanalysis, 4(1), 7-23. https://doi.org/10.1080/15294145.2002.10773372

Mungunsong, F. (2009). Faktor Intrapersonal, Interpersonal, dan Kultural Pendukung Efektivitas Kepemimpinan Perempuan Pengusaha dari Empat Kelompok Etnis di Indonesia. Makara, Sosial Humaniora, 13(1), 19-28.

Ngai, E. W. T., Tao, S. S. C., \& Moon, K. K. L. (2015). Social media research: Theories, constructs, and conceptual frameworks. International Journal of Information Management, 35(1), 33-44. https://doi.org/10.1016/j.ijinfomgt.2014.09.004

O'Donnell, N. H. (2018). Storied Lives on Instagram: Factors Associated With the Need for Personal-Visual $\begin{array}{lllll}\text { Identity. Visual } & \text { Communication }\end{array}$ https://doi.org/10.1080/15551393.2018.1490186

Permatasari, N., \& Trijayanto, D. (2017). Motif Eksistensi melalui Penggunaan Hashtag (\#OOTD) di Media Sosial Instagram. $\quad$ Promedia, 252 3(2), journal.uta45jakarta.ac.id/index.php/kom/article/view/952

Peterson, R. D., Grippo, K. P., \& Tantleff-Dunn, S. (2008). Empowerment and powerlessness: A closer look at the relationship between feminism, body image and eating disturbance. Sex Roles, 58(9-10), 639648. https://doi.org/10.1007/s11199-007-9377-z

Plant, S. (1997). Zeroes + Ones: Digital Women + the New Technoculture. Fourt Estate.

Purnamawati, A. (2012). Media, Perempuan, dan Kemandirian. In Citra Perempuan Dalam Media (pp. 5764). Balai Pengkajian dan Pengembangan Komunikasi dan Informatika.

Purwaningtyas, M. P. F., \& Alicya, D. A. (2020). The Fragmented Self: Having Multiple Accounts in Instagram Usage Practice among Indonesian Youth. Jurnal Media Dan Komunikasi Indonesia, 1(September), 171-182. https://journal.ugm.ac.id/jmki/article/view/58459

Putri, R. D. H. (2018). The Influencer and Hedonist Lifestyle of Digital Society. Jisiera: The Journal of Islamic Studies and International Relations, 3(1), 1-14. http://www.jisiera.insiera.org/index.php/jisiera/article/view/35

Rachmansyah, M., \& Supratman, L. P. (2020). Peran Media Instagram dalam Memasarkan Produk Fashion Dollies. Jurnal Studi Komunikasi Dan Media, 24(1), 73-90. https://doi.org/10.31445/jskm.2020.2865

Rahayu, A. W. (2015). Perempuan Dan Belenggu Peran Kultural. Jurnal Perempuan. https://doi.org/http://www.jurnalperempuan.org/wacana-feminis/perempuan-dan-belenggu-perankultural

Rahmadi, I. F., \& Hayati, E. (2020). Literasi Digital, Massive Open Online Courses, dan Kecakapan Belajar Abad 21 Mahasiswa Generasi Milenial. Jurnal Studi Komunikasi Dan Media, 24(1), 91. https://doi.org/10.31445/jskm.2020.2486

Rampton, M. (2008). Four Waves of Feminism. Pacific Magazine, 1-4. https://www.pacificu.edu/about/media/four-waves-feminism

Rehman, A. U., Jiang, A., Rehman, A., Paul, A., din, S., \& Sadiq, M. T. (2020). Identification and role of opinion leaders in information diffusion for online discussion network. Journal of Ambient Intelligence and Humanized Computing, 0123456789. https://doi.org/10.1007/s12652-019-01623-5

Rettberg, J. W. (2018). Self-Representation in Social Media. SAGE Handbook of Social Media, 429-443. https://bora.uib.no/bora-xmlui/bitstream/handle/1956/13073/SelfRepresentation_in_Social_Media.pdf?sequence $=1$

Rogers Sally; Chamberlin, Judi; Langer Marsha; Crean, T. (1997). a Consumer Constructed Scale To Measure Empowerment. In Psychiatric srvices (Vol. 48, Issue 8, pp. 1042-1048).

Rosyidah, F. N., \& Nurdin, M. F. (2018). Perilaku Menyimpang : Media Sosial Sebagai Ruang Baru Dalam Tindak Pelecehan Seksual Remaja. Jurnal Pemikiran Dan Penelitian Sosiologi, 2(2), 38-48.

Ruiz-Gomez, A. (2019). Digital Fame and Fortune in the age of Social Media: A Classification of social media influencers. ADResearch ESIC International Journal of Communication Research, 19(19), 0829. https://doi.org/10.7263/adresic-019-01

Saputri, R. K., \& Himam, F. (2015). Mindset Wanita Pengusaha Sukses. Jurnal Psikologi, 42(2), 157. 
https://doi.org/10.22146/jpsi.7170

Schlegelmilch, J., Sury, J., Brooks, J., \& Chandler, T. (2020). A Philanthropic Approach to Supporting Emergent Disaster Response and Recovery. Disaster Medicine and Public Health Preparedness, 14(1), 158-160. https://doi.org/10.1017/dmp.2019.97

Sender, K., \& Decherney, P. (2016). Stuart Hall lives: cultural studies in an age of digital media. Critical Studies in Media Communication, 33(5), 381-384. https://doi.org/10.1080/15295036.2016.1244725

Silva, M. J. de B., Farias, S. A. de, Grigg, M. K., \& Barbosa, M. de L. de A. (2020). Online Engagement and the Role of Digital Influencers in Product Endorsement on Instagram. Journal of Relationship Marketing, 19(2), 133-163. https://doi.org/10.1080/15332667.2019.1664872

Sloan, L., \& Quan-Haase, A. (2017). Introduction to the Handbook of Social Media Research Methods: Goals, Challenges and Innovations. In L. Sloan \& A. Quan-Haase (Eds.), The SAGE Handbook of Social Media Research Methods (pp. 1-10). Sage Publications. https://doi.org/10.4135/9781473983847

Smith, L. R., \& Sanderson, J. (2015). I'm Going to Instagram It! An Analysis of Athlete Self-Presentation on Instagram. Journal of Broadcasting and Electronic Media, 59(2), 342-358. https://doi.org/10.1080/08838151.2015.1029125

Statista.com. (2021). Leading countries based on Instagram audience size as of January 2021.

Supratman, L. P. (2012). Representasi Citra Perempuan di Media. Observasi, 10(1), 29-40.

Tapscott, D. (2014). The Digital Economy ANNIVERSARY EDITION: Rethinking Promise and Peril in the Age of Networked Intelligence (2nd ed.). McGraw-Hill.

Thumim, N. (2012). Self-Representation and Digital Culture. Palgrave Macmillan.

Tortajada, I., Araüna, N., \& Martínez, I. J. (2013). Advertising stereotypes and gender representation in social networking sites. Comunicar, 21(41), 177-186. https://doi.org/10.3916/C41-2013-17

Ughetto, E., Rossi, M., Audretsch, D., \& Lehmann, E. E. (2020). Female entrepreneurship in the digital era. Small Business Economics, 55(2), 305-312. https://doi.org/10.1007/s11187-019-00298-8

Utami, S. (2019). An Nisa ' Jurnal Studi Gender dan Anak Eksistensi Perkembangan Perekonomian Perempuan di Era Digitalisasi. Jurnal Studi Gender Dan Anak, 12(1), 596-609.

Van Ouytsel, J., Walrave, M., Ojeda, M., Rey, R. Del, \& Ponnet, K. (2020). Adolescents' sexy selfpresentation on instagram: An investigation of their posting behavior using a prototype willingness model perspective. International Journal of Environmental Research and Public Health, 17(21), 1-15. https://doi.org/10.3390/ijerph17218106

Vandenbosch, L. P. (2017). Media Representation: Health and Body Images. The International Encyclopedia of Media Effects, 1-13. https://doi.org/10.1002/9781118783764.wbieme0145 
JURNAL STUDI KOMUNIKASI DAN MEDIA

Vol. 25 No. 2 Desember 2021 Hal : 131 - 150 